The Open Petroleum Engineering
Journal
CrossMark

\title{
PREFACE
}

\section{Some Comments on Shale Opportunities}

The development of oil and gas production from shales in North America over the last 7 or so years has had a huge impact across, not only the hydrocarbon world but now into the world economy as oil and gas prices have been driven downwards to very low levels. The benefits in this recovering world economy have been material but have naturally been followed by the economic pain experienced by the producers.

The North American success has naturally led to seeking international shale opportunities and several potential major sources have been identified. However many of these opportunities have met with significant environmental push back at the exploration stage apart from having to face the much higher international costs. Costs are inevitably much higher, (typically multiples of North American costs), in working in areas without the competitive benefits of significant drilling, service, pipeline and related infrastructure that help to ensure relatively low costs in North America.

Apart from the lack of the extensive availability of pipeline networks the infrastructure issue extends to the narrow roads and bridges in areas such as the heavily populated European countries. Environmentally there will inevitably be difficulties at the development stage when the potential need for drilling large numbers of wells becomes necessary. Technology may well be able to deal with these issues given time and the right economic environment.

The price drops themselves have put in question the longer-term on-going viability of the shale revolutions in North America as well as elsewhere - if it was not indeed already being questioned because of the significant declines in production rates experienced by most shale production. Historically the industry has a track record of being able to adjust to current realities over time often improving both recovery and production rates in the process.

One benefit of the price demise may well be a significant reduction in the North American long-term drilling and completion costs for shale developments and significant improvements in technology. If that occurs, as many expect, then international development opportunities will become much more feasible as these costs translate into the international arena although many of the logistical/environmental/political challenges will remain.

In that arena it is timely to consider the position of shale across a wider technical and practical reality and the following thematic issue paper and its adjuncts try to put todays reality in context.

Peter D. Gaffney

Independent Consultant

Torino

Italy

\section{(C) Peter D. Gaffney; Licensee Bentham Open.}

This is an open access article licensed under the terms of the Creative Commons Attribution-Non-Commercial 4.0 International Public License (CC BY-NC 4.0) (https://creativecommons.org/licenses/by-nc/4.0/legalcode), which permits unrestricted, non-commercial use, distribution and reproduction in any medium, provided the work is properly cited. 